\title{
PENGARUH KOMPENSASI FINANSIAL, GAYA KEPEMIMPINAN TRANSFORMASIONAL, DAN MOTIVASI KERJA TERHADAP KEPUASAN KERJA KARYAWAN
}

\author{
I Gede Wira Satriawan ${ }^{1}$ \\ I Komang Ardana ${ }^{2}$ \\ ${ }^{1,2}$ Fakultas Ekonomi dan Bisnis Universitas Udayana (Unud), Bali, Indonesia \\ E-mail: wirasatriawan1111@gmail.com
}

\begin{abstract}
ABSTRAK
Tujuan penelitian ini adalah untuk mengetahui pengaruh kompensasi finansial, gaya kepemimpinan transformasional, dan motivasi kerja terhadap kepuasan kerja karyawan. Penelitian ini dilakukan di PT. Dua Ikan Lembongan, yang memiliki 3 cabang di Bali. Jumlah sampel dalam penelitian ini sebanyak 45 orang karyawan yang ditentukan dengan metode sampling jenuh. Pengumpulan data dilakukan melalui wawancara dan kuesioner. Teknik analisis data yang digunakan adalah analisis regresi linear berganda. Hasil penelitian menunjukan bahwa variabel kompensasi finansial, gaya kepemimpinan transformasional, dan motivasi kerja secara parsial berpengaruh positif dan signifikan terhadap kepuasan kerja karyawan. Sebesar 89,9 persen, variabel kepuasan kerja dipengaruhi oleh kompensasi finansial, gaya kepemimpinan transformasional, dan motivasi kerja, sedangkan sisanya sebesar 10,1 persen dipengaruhi oleh variabel lain di luar penelitian. Perusahaan sebaiknya memperhatikan kompensasi finansial, gaya kepemimpinan transformasional, dan motivasi kerja terhadap kepuasan kerja karyawan, karena pentingnya aspek-aspek tersebut yang akan berdampak pada kinerja organisasi.
\end{abstract}

Kata kunci: kompensasi finansial, gaya kepemimpinan transformasional, motivasi kerja, kepuasan kerja

\begin{abstract}
The purpose of this study was to determine the effect of financial compensation, transformational leadership style, and work motivation on employee job satisfaction. This research was conducted at PT. Two Lembongan Fish, which has 3 branches in Bali. The number of samples in this study were 45 employees who were determined by the saturated sampling method. Data collection was done through interviews and questionnaires. As much as 89.9 percent, job satisfaction variables are affected by financial compensation, transformational leadership style, and work motivation, while the rest of 10.1 percent is influenced by other variables outside the study. Companies should pay attention to financial compensation, transformational leadership style, and work motivation to employee job satisfaction, because of the importance of these aspects that will impact on organizational performance.
\end{abstract}

Keywords: financial compensation, transformational leadership style, work motivation, job satisfaction 


\section{PENDAHULUAN}

Guna menghadapi persaingan di era global saat ini, perusahaan dituntut untuk bekerja lebih efisien dan efektif. Persaingan yang semakin ketat menyebabkan perusahaan dituntut untuk mampu meningkatkan daya saing dalam rangka menjaga kelangsungan hidup perusahaan. Perusahaan merupakan salah satu organisasi yang menghimpun orang-orang yang biasa disebut dengan karyawan atau pegawai untuk menjalankan kegiatan atau pekerjaan dalam perusahaan. Hampir di semua perusahaan mempunyai tujuan yaitu memaksimalkan keuntungan dan nilai bagi perusahaan, dan juga untuk meningkatkan kesejahteraan pemilik dan karyawan.

Kepuasan kerja karyawan merupakan salah satu topik yang senantiasa menarik dan dianggap penting, baik oleh ilmuwan maupun praktisi, justru karena kepuasan kerja dipandang dapat memengaruhi jalannya organisasi secara keseluruhan serta peningkatan kerja karyawan. Setiap organisasi pasti memiliki tujuan untuk mencapai kinerja yang seoptimal mungkin. Peningkatan kinerja organisasi yang seoptimal mungkin tidak terlepas dari kepuasan kerja karyawan, yang merupakan salah satu faktor yang menentukan kinerja organisasi. Untuk dapat meraih prestasi atau kinerja karyawan sesuai dengan cita-cita dan harapan perusahaan, maka seorang pemimpin dituntut untuk memiliki sebuah kebijakan maupun program yang ditujukan kepada para karyawannya agar setiap individu karyawan mendapatkan tingkat kepuasan kerja yang tinggi sehingga dapat berkontribusi secara optimal kepada perusahaan.

Kepuasan kerja menurut (Robbins \& Judge, 2017) merupakan sikap umum seorang individu atau karyawan terhadap pekerjaannya. Seorang dengan tingkat 
kepuasan kerja tinggi menunjukan sikap yang positif terhadap pekerjaannya, sebaliknya seorang yang tidak puas akan menunjukan sikap yang negatif terhadap pekerjaannya. Menurut Robbins (2001 : 149) faktor yang memengaruhi kepuasan kerja antara lain, (1) kerja yang secara mental menantang, (2) penghargaan yang pantas, (3) Kondisi kerja yang mendukung, (4) rekan sekerja yang mendukung, (5) kesesuaian kepribadian dan pekerjaan, dan (6) ada dalam agen, dan langkah tepat yang harus diambil oleh pimpinan perusahaan diantaranya adalah pemberian kompensasi pada setiap peningkatan prestasi, lingkungan kerja yang baik seperti rekan dalam bekerja, dan pemberian motivasi yang diberikan oleh atasan kepada para karyawan.

PT. Dua Ikan Lembongan merupakan perusahaan yang bergerak dibidang jasa pariwisata air atau travelling. Organisasi ini memiliki 3 kantor cabang, yaitu di Sanur, Karangasem, dan Lembongan. Dalam era globalisasi saat ini, PT. Dua Ikan juga menanggapi dengan serius permasalahan yang muncul, yaitu persaingan yang semakin ketat antar pesaing yang sejenis. Oleh sebab itu, manajemen atau atasan harus memperhatikan permasalahan yang muncul di dalam perusahaan untuk bisa mencapai kinerja yang seoptimal mungkin dan mampu bersaing dengan para pesaing. Dari hasil pra survei yang telah dilakukan dengan metode wawancara terhadap beberapa karyawan, diperoleh informasi dan fakta terkaitnya tingkat kepuasan kerja karyawan yang diterima.

Dessler (2007:46), kompensasi karyawan adalah semua bentuk pembayaran atau hadiah yang diberikan kepada karyawan dan muncul dari pekerjaan mereka. Ardana dkk. (2012:153) menyatakan bahwa kompensasi finansial adalah segala 
sesuatu yang diterima pegawai dalam bentuk uang (finansial) sebagai balas jasa atau kontribusi terhadap perusahaan atau organisasi. Pada faktor kompensasi finansial ditemukan adanya keluhan salah satu pegawai yang menyatakan bahwa gaji yang diterima tidak sesuai dengan pekerjaan yang dikerjakan, dan kecemburuan sosial antara karyawan (guide diving) dengan karyawan (receptionist), dimana kedua jenis pekerjaan tersebut memiliki tingkat bonus yang berbeda. Hal ini didukung dari penelitian Siregar (2011) dan Muguongo et al. (2015) yang menyatakan bahwa kompensasi finansial berpengaruh positif dan signifikan terhadap kepuasan kerja.

Pengertian gaya kepemimpinan transformasional adalah seberapa besar pengaruh pemimpin antara pelaksanaan kinerja dan harapan karyawan. Gaya kepemimpinan transformasional mengacu pada pemimpin yang berhasil menggerakkan karyawan melampaui kepentingan diri secara langsung melalui pengaruh ideal atau kharisma, inspirasi, stimulasi intelektual, atau pertimbangan individual (Pranantio dkk., 2014) dalam (Yudi \& Adnyani, 2015). Berdasarkan observasi yang dilakukan telah ditemukan beberapa kali adanya miskomunikasi antara atasan dengan bawahan yang berakibat munculnya rasa ketidaknyamanan dalam bekerja. Hal ini didukung dari penelitian Mujkic et al. (2014), dan Alghamdi et al. (2018) menyatakan bahwa gaya kepemimpinan transformasional berpengaruh positif dan signifikan terhadap kepuasan kerja karyawan.

Motivasi merupakan kekuatan yang mendorong seseorang untuk melakukan suatu tindakan, pada hakekatnya secara internal dan eksternal yang dapat berpengaruh positif atau negatif, untuk mengarahkannya sangat bergantung kepada 
ketangguhan sang manajer. Sedangkan motivasi kerja adalah sesuatu yang menimbulkan dorongan atau semangat kerja atau pendorong semangat kerja (Ardana dkk., 2012:193). Pada faktor ini terlihat menurunnya semangat kerja karyawan. Hal tersebut terjadi dikarenakan kurangnya stimulus yang mampu menggerakan motivasi kerja karyawan seperti, bonus, kondisi lingkungan kerja yang kondusif, dan fasilitas rekreasi. Diperkuat oleh beberapa penelitian dari Homberg et al. (2015) dan Sarita \& Agustia (2011) yang mendukung bahwa motivasi kerja berpengaruh positif dan signifikan terhadap kepuasan kerja.

Kepuasan kerja menurut (Robbins \& Judge, 2017) merupakan sikap umum seorang individu atau karyawan terhadap pekerjaannya. Seorang dengan tingkat kepuasan kerja tinggi menunjukan sikap yang positif terhadap pekerjaannya, sebaliknya seorang yang tidak puas akan menunjukan sikap yang negatif terhadap pekerjaannya. Two factor theory menjelaskan bahwa kepuasan kerja berbeda dengan ketidakpuasan kerja (Hezberg, 1959) dalam Priansa (2014). Artinya kepuasan dan ketidakpuasan terhadap pekerjaan itu tidak merupakan suatu variabel yang berkelanjutan. Teori ini membagi situasi yang memengaruhi sikap pegawai terhadap pekerjaan menjadi dua (2) kelompok penting, yaitu kelompok dissatisfiers (hygiene factors) dan satisfiers (motivator). 1) Dissatisfiers. Meliputi hal-hal seperti: gaji/upah, pengawasan, hubungan antar pribadi, kondisi kerja, dan status. Jumlah tertentu dari dissatisfiers diperlukan untuk memenuhi dorongan biologis serta kebutuhan dasar pegawai seperti kebutuhan keamanan dan kelompok. Apabila kebutuhan-kebutuhan tersebut tidak terpenuhi, pegawai akan merasa tidak puas, tetapi jika besarnya dissatisfiers memadai untuk kebutuhan tersebut, pegawai tidak 
lagi kecewa tetapi belum terpuaskan. Pegawai hanya terpuaskan jika terdapat jumlah yang memadai untuk faktor-faktor pekerjaan yang dinamakan dissatisfiers. 2) Satisfiers atau Motivators. Meliputi faktor-faktor atau situasi yang dibuktikannya sebagai sumber kepuasan kerja, seperti prestasi, pengakuan, tanggung jawab, kemajuan, dan kemungkinan untuk berkembang. Satisfiers merupakan karakteristik pekerjaan yang relevan dengan urutan kebutuhan-kebutuhan yang lebih tinggi pada pegawai serta perkembangan psikologisnya. Adanya faktor ini akan menimbulkan kepuasan kerja, tetapi tidak adanya faktor ini tidaklah selalu menimbulkan ketidakpuasan. Perbaikan gaji dan kondisi kerja tidak akan menimbulkan kepuasan bagi pegawai, namun hanya mengurangi ketidakpuasan, yang mampu memacu pegawai untuk dapat bekerja dengan baik dan bergairah hanyalah kelompok satisifiers.

Menurut Robbins (2001:149) faktor yang memengaruhi kepuasan kerja yaitu kerja yang secara mental menantang, dimana karyawan cenderung lebih suka pekerjaan-pekerjaan yang memberi mereka kesempatan untuk menggunakan keterampilan dan kemampuan mereka dan menawarkan beragam tugas, kebebasan, umpan balik mengenai betapa baik mereka mengerjakannya.

Penghargaan yang pantas, dimana para karyawan menginginkan sistem upah dan kebijakan promosi yang mereka persepsikan sebagai adil, gaji dan upah yang mereka dapat sesuai dengan kinerjanya, dan segaris dengan pengharapan mereka.

Kondisi kerja yang mendukung, dimana karyawan peduli akan lingkungan kerja baik untuk kenyamanan pribadi maupun untuk memudahkan mengerjakan 
tugas yang baik. Dalam beberapa studi memperagakan bahwa karyawan menyukai keadaan sekitar fisik yang tidak berbahaya atau merepotkan.

Rekan sekerja yang mendukung, dimana orang-orang mendapatkan lebih daripada sekedar uang atau prestasi yang berwujud dari dalam kerja. Bagi kebanyakan karyawan, kerja juga mengisi kebutuhan akan interaksi sosial. Sehingga dengan adanya rekan kerja yang ramah akan mendukung kepuasan kerja yang meningkat. Perilaku atasan juga sebagai determinan utama dari kepuasan. Dari studi lain dikatakan bila kepuasan karyawan dapat ditingkatkan bila penyelia bersifat ramah dan dapat memahami, memberikan pujian untuk kinerja yang baik, mendengarkan pendapat karyawan, dan menunjukan suatu minat pribadi pada mereka.

Kesesuaian kepribadian dan pekerjaan, dimana kecocokan yang tinggi antara kepribadian seorang karyawan dan pekerjaannya akan menghasilkan seorang individu yang lebih terpuaskan. Dimana orang-orang yang tipe kepribadiannya sama dengan pekerjaan yang mereka pilih, seharusnya mendapatkan bahwa mereka mempunyai bakat dan kemampuan yang tepat untuk memenuhi tuntutan dari pekerjaan mereka, dengan demikian lebih besar kemungkinan untuk berhasil pada pekerjaan tersebut.

Ada dalam gen, dimana sebanyak 30 persen dari kepuasan individual dapat dijelaskan oleh keturunan. Riset lainnya mengemukakan bahwa sebagian besar dari kepuasan beberapa orang ditentukan secara genetis. Artinya, disposisi seseorang terhadap hidup-positif atau negatif ditentukan oleh bentukan genetikanya, bertahan sepanjang waktu, dan dibawa serta ke dalam disposisinya terhadap kerja. 
Menurut teori dua faktor (Two factor theory) bahwa faktor-faktor yang menjadi sumber ketidakpuasan karyawan mencakup kompensasi, yaitu gaji/upah. Menurut Dessler (2007:46), kompensasi karyawan adalah semua bentuk pembayaran atau hadiah yang diberikan kepada karyawan dan muncul dari pekerjaan mereka. Ardana dkk. (2012:153) menyatakan bahwa kompensasi finansial adalah segala sesuatu yang diterima pegawai dalam bentuk uang (finansial) sebagai balas jasa atau kontribusi terhadap perusahaan atau organisasi.

Robbins (2001:149) menyatakan beberapa indikator mengenai kepuasan kerja yaitu sebagai berikut, (1) kerja yang secara mental menantang, (2) penghargaan yang pantas, (3) kondisi kerja yang mendukung, (4) rekan sekerja yang mendukung, dan (5) kesesuaian kepribadian dan pekerjaan.

Menurut teori dua faktor (Two factor theory) bahwa faktor-faktor yang menjadi sumber ketidakpuasan karyawan mencakup kompensasi, yaitu gaji/upah. Menurut Dessler (2007:46), kompensasi karyawan adalah semua bentuk pembayaran atau hadiah yang diberikan kepada karyawan dan muncul dari pekerjaan mereka. Ardana dkk. (2012:153) menyatakan bahwa kompensasi finansial adalah segala sesuatu yang diterima pegawai dalam bentuk uang (finansial) sebagai balas jasa atau kontribusi terhadap perusahaan atau organisasi.

Rivai (2005:360) menyatakan jenis-jenis kompensasi finansial adalah sebagai berikut : 1) Gaji, merupakan balas jasa yang diterima karyawan dalam bentuk uang sebagai seorang karyawan yang memberikan sumbangan tenaga dan pikiran dalam mencapai tujuan organisasi. 2) Upah, merupakan imbalan finansial yang diberikan kepada karyawan berdasarkan jam kerja, jumlah barang yang 
I Gede Wira Satriawan. Pengaruh Kompensasi Finansial .....

dihasilkan atau banyaknya pelayanan yang telah diberikan. 3) Insentif, merupakan imbalan langsung yang diberikan karyawan karena kinerjanya melebihi standar yang telah ditentukan perusahaan. 4) Kompensasi tidak langsung / fringe benefit, merupakan tambahan yang diberikan berdasarkan kebijakan perusahaan terhadap semua karyawan sebagai upaya meningkatkan kesejahteraan karyawan seperti, fasilitas asuransi, tunjangan pensiun, dan sebagainya.

Teori kepemimpinan transformasional juga mengakui pentingnya power dan proses memengaruhi (influence processes). Hubungan pemimpin-pengikut dipandang sebagai satu intensi emosi yang mana pengikut memberikan kepercayaan dan keyakinan yang besar kepada pemimpin (Bass et al. 1987; Burns, 1978) dalam (Narsa, 2012). Bass (1985) dalam (Narsa, 2012) menyebutnya karisma, inspirasi, pertimbangan (consideration) individual, dan stimulasi intelektual sebagai empat karakteristik yang membentuk kepemimpinan transformasional.

Bass \& Avolio dalam Yukl (2010:304) mengemukakan adanya empat ciri karakteristik kepemimpinan transformasional dan indikatornya, yaitu: 1) Kharisma (Charisma) / Pengaruh yang ideal, adalah perilaku pemimpin yang memberikan visi dan misi, memunculkan rasa bangga, serta mendapatkan respek dan kepercayaan bawahan. 2) Inspirasi (Inspiration), adalah perilaku pemimpin yang mampu mengkomunikasikan harapan yang tinggi, menyampaikan visi bersama secara menarik, dan menginspirasi bawahan untuk mencapai tujuan yang menghasilkan kemajuan penting bagi organisasi. 3) Rangsangan intelektual (Intellectual stimulation), adalah perilaku pemimpin yang mampu meningkatkan kreativitas dan 
inovasi bawahan, meningkatkan kepercayaan, dan pemecahan masalah secara cermat. 4) Perhatian individual (Individualized consideration), adalah perilaku pemimpin yang memperlakukan masing-masing bawahan sebagai seorang individu dengan kebutuhan, kemampuan, dan aspirasi yang berbeda, serta melatih dan memberikan arahan.

Kepemimpinan transformasional menurut Bass dalam (Yukl, 2010:305) adalah pemimpin yang mengubah dan memotivasi para pengikut sehingga merasakan kepercayaan, kekaguman, kesetiaan dan penghormatan terhadap pemimpin.

Motivasi merupakan kekuatan yang mendorong seseorang untuk melakukan suatu tindakan, pada hakekatnya secara internal dan eksternal yang dapat berpengaruh positif atau negatif, untuk mengarahkannya sangat bergantung kepada ketangguhan manajer. Sedangkan motivasi kerja adalah sesuatu yang menimbulkan dorongan atau semangat kerja atau pendorong semangat kerja (Ardana dkk., 2012:193). Motivasi menurut Robbins \& Judge (2017:222) merupakan proses yang menjelaskan intensitas, arah, dan ketekunan seorang individu untuk mencapai tujuannya di dalam suatu pekerjaan.

Berdasarkan uraian diatas, maka dapat dikatakan bahwa motivasi merupakan suatu kebutuhan yang membuat seseorang merasa terdorong untuk melakukan sesuatu hal. Dengan adanya kebutuhan, akan menimbulkan seseorang untuk bertingkah laku tertentu di dalam usahanya untuk mencapai suatu tujuan.

Ardana dkk. (2012:193) motivasi seseorang juga dapat timbul karena beberapa hal, terdapat beberapa proses atau indikator yang dapat menimbulnya 
I Gede Wira Satriawan. Pengaruh Kompensasi Finansial .....

motivasi seseorang, antara lain: (1) penempatan kerja yang tepat, (2) kondisi kerja yang menyenangkan, (3) fasilitas rekreasi, (4) promosi yang objektif, (5) penjagaan kesehatan, (6) latihan sistematik, (7) pekerjaan yang terjamin, (8) pemberian informasi tentang perusahaan, dan (9) keikutsertaan wakil-wakil karyawan dalam pengambilan keputusan.

Hasil penelitian yang dilakukan oleh Adeoye et al. (2014) yang berjudul Compensation Management and Employee Job Satisfaction: A Case of Nigeria menyatakan bahwa pengaruh kompensasi finansial terhadap kepuasan kerja adalah positif dan signifikan, begitu pula dengan penelitian dari Sedhana \& Mudiartha (2014) Pada Karma Jimbaran, Bali membuktikan bahwa kompensasi yang diterima pegawai akan secara positif berpengaruh terhadap kepuasan kerja karyawan. Hasil penelitian ini didukung oleh teori dua faktor yang menyatakan kepuasan atau ketidakpuasan kerja dapat dihubungkan dengan pengupahan (Wibowo, 2012:502) dalam Sedhana \& Mudiartha (2014). Begitu juga dengan penelitian yang dilakukan oleh Anas (2013), Mabaso \& Dlamini (2017), dan Muguongo et al. (2015) yang memiliki hasil bahwa terdapat pengaruh positif yang signifikan antara kompensasi finansial terhadap kepuasan kerja karyawan.

$\mathrm{H}_{1}$ : Kompensasi finansial berpengaruh positif dan signifikan terhadap kepuasan kerja karyawan

Penelitian yang dilakukan oleh Reidy et al. (2016) yang berjudul Pengaruh Gaya Kepemimpinan Transformasional dan Transaksional Terhadap Kepuasan Kerja Karyawan pada CV Kalingga Jaya di Jakarta menunjukkan bahwa pengaruh antara kepemimpinan transformasional dengan kepuasan kerja adalah positif dan signifikan. Hasil penelitian lainnya oleh Hanifah \& Arifin (2016), Aqmarina (2016) 
, Voon et al. (2011), Belias \& Athanasios (2014), Mujkic et al. (2014), dan Alghamdi et al. (2018) memberikan hasil bahwa gaya kepemimpinan transformasional berpengaruh positif dan signifikan terhadap kepuasan kerja karyawan.

$\mathrm{H}_{2}$ : Gaya kepemimpinan transfromasional berpengaruh positif dan signifikan terhadap kepuasan kerja karyawan

Penelitian yang dilakukan Murti \& Srimulyani (2013) dengan judul Pengaruh Motivasi Terhadap Kinerja Pegawai dengan Variabel Pemediasi Kepuasaan Kerja pada Pdam Kota Madiun membuktikan pengaruh positif yang signifikan antara motivasi kerja dengan kepuasan kerja karyawan. Nadia (2011), Rajan (2015), Breaugh et al. (2017) dan Olutade et al. (2015) juga memberikan hasil penelitian bahwa motivasi kerja berpengaruh positif dan signifkan terhadap kepuasan kerja. Hasil temuan dalam studi yang dilakukan oleh Sarita \& Agustia (2011) yang berjudul Pengaruh Gaya Kepemimpinan Situasional, Motivasi Kerja, Locus Of Control Terhadap Kepuasan Kerja dan Prestasi Kerja Auditor menunjukkan bahwa motivasi kerja terbukti berpengaruh positif dan signifikan terhadap kepuasan kerja. Semakin tinggi motivasi kerja auditor, makin tinggi tingkat kepuasan kerja seorang auditor.

$\mathrm{H}_{3}$ : Motivasi kerja berpengaruh positif dan signifikan terhadap kepuasan kerja karyawan

\section{METODE PENELITIAN}


Penelitian ini dilakukan pada PT. Dua Ikan Lembongan dikarenakan belum adanya penelitian yang pernah dilakukan di lokasi tersebut dan memiliki indikasi permasalahan perihal kepuasan kerja yang rendah. PT. Dua Ikan Lembongan memiliki 3 tempat di Bali. Obyek penelitian ini adalah kompensasi finansial, gaya kepemimpinan transformasional, motivasi kerja, dan kepuasan kerja karyawan.

Variabel bebas yang digunakan dalam penelitian ini yaitu kompensasi finansial, gaya kepemimpinan transformasional, dan motivasi kerja yang dapat disimbolkan dengan $\mathrm{X}_{1}, \mathrm{X}_{2}$, dan $\mathrm{X}_{3}$. Variabel terikat yang digunakan dalam penelitian ini yaitu kepuasan kerja yang dapat disimbolkan dengan Y.

Dalam penelitian ini data kuantitatif yang dimaksud adalah jumlah karyawan serta jumlah skor jawaban kuisioner yang telah dikuantitatifkan dengan pembobotan jawaban responden yang terdiri dari data mengenai kompensasi finansial, gaya kepemimpinan transformasional, motivasi kerja, serta kepuasan kerja karyawan dari perusahaan. Data kualitatif dalam penelitian ini ialah gambaran umum perusahaan.

Populasi penelitian ini adalah seluruh karyawan PT. Dua Ikan Lembongan yaitu sebanyak 45 orang. Teknik pengambilan sampel dilakukan dengan sampling jenuh, yaitu dengan cara mengambil seluruh populasi sebagai sampel. Teknik ini dipilih karena jumlah dari populasi tergolong kecil, sehingga seluruh populasi digunakan sebagai sampel dalam penelitian ini. 


\begin{tabular}{llc}
\hline No. & \multicolumn{1}{c}{ Jabatan } & Populasi/Sampel \\
\hline 1 & Administrasi & 4 \\
2 & Receptionist & 5 \\
3 & Diving Guide & 16 \\
4 & Diving Instructur & 8 \\
5 & Reservasi & 4 \\
6 & Kapten Boat & 4 \\
7 & Kompresor & 4 \\
& Jumlah & 45 \\
\hline
\end{tabular}

Sumber: PT. Dua Ikan Lembongan, Tahun 2017

Model analisis yang digunakan dalam penelitian ini adalah analisis regresi linear berganda dengan menggunakan bantuan aplikasi SPSS (Statistical Package for Social Science) versi 17.0. Model ini digunakan untuk mengetahui sejauh mana hubungan antar variabel terikat dengan variabel bebasnya baik secara serempak maupun secara parsial (Sugiyono, 2013:277).

Adapun model analisis dari regresi berganda yang dimaksud adalah sebagai persamaan berikut :

$$
\mathrm{Y}=\mathrm{b}_{1} \mathrm{X}_{1}+\mathrm{b}_{2} \mathrm{X}_{2}+\mathrm{b}_{3} \mathrm{X}_{3}+\varepsilon
$$

Dimana :

$$
\begin{array}{ll}
\mathrm{Y} & =\text { Kepuasan kerja } \\
\mathrm{b}_{1}-\mathrm{b}_{3} & =\text { Koefisien regresi dari masing-masing variabel } \\
\mathrm{X}_{1} & =\text { Kompensasi finansial } \\
\mathrm{X}_{2} & =\text { Gaya kepemimpinan transformasional } \\
\mathrm{X}_{3} & =\text { Motivasi kerja } \\
\varepsilon & =\text { Error }
\end{array}
$$

\section{HASIL PENELITIAN DAN PEMBAHASAN}

Instrumen dikatakan valid apabila korelasi antara skor faktor dengan skor total bernilai positif dan nilainya lebih dari 0,30 ( $\mathrm{r}>0,3)$. Hasil uji validitas menunjukkan bahwa butir-butir pertanyaan dalam instrumen penelitian tersebut valid.

\section{Tabel 2.}




\section{Hasil Uji Validitas}

\begin{tabular}{|c|c|c|c|c|}
\hline No & Variabel & $\begin{array}{c}\text { Item } \\
\text { Pertanyaan }\end{array}$ & $\begin{array}{c}\text { Korelasi Item } \\
\text { Total }\end{array}$ & Keterangan \\
\hline \multirow{6}{*}{1} & \multirow{6}{*}{ Kepuasan Kerja (Y) } & $\mathrm{Y} 11$ & 0,857 & Valid \\
\hline & & $\mathrm{Y} 12$ & 0,859 & Valid \\
\hline & & $\mathrm{Y} 13$ & 0,745 & Valid \\
\hline & & Y14 & 0,820 & Valid \\
\hline & & Y15 & 0,851 & Valid \\
\hline & & Y16 & 0,876 & Valid \\
\hline \multirow{5}{*}{2} & \multirow{5}{*}{$\begin{array}{l}\text { Kompensasi Finansial } \\
\text { (X1) }\end{array}$} & $\mathrm{X} 11$ & 0,596 & Valid \\
\hline & & $\mathrm{X} 12$ & 0,959 & Valid \\
\hline & & $\mathrm{X} 13$ & 0,943 & Valid \\
\hline & & $\mathrm{X} 14$ & 0,927 & Valid \\
\hline & & $\mathrm{X} 15$ & 0,891 & Valid \\
\hline \multirow{4}{*}{3} & \multirow{4}{*}{$\begin{array}{l}\text { Gaya Kepemimpinan } \\
\text { Transformasional (X2) }\end{array}$} & $\mathrm{X} 21$ & 0,848 & Valid \\
\hline & & $\mathrm{X} 22$ & 0,853 & Valid \\
\hline & & $\mathrm{X} 23$ & 0,922 & Valid \\
\hline & & $\mathrm{X} 24$ & 0,862 & Valid \\
\hline \multirow{5}{*}{4} & \multirow{5}{*}{ Motivasi Kerja (X3) } & $\mathrm{X} 31$ & 0,686 & Valid \\
\hline & & $\mathrm{X} 32$ & 0,844 & Valid \\
\hline & & $\mathrm{X} 33$ & 0,853 & Valid \\
\hline & & X34 & 0,836 & Valid \\
\hline & & $\mathrm{X} 35$ & 0,864 & Valid \\
\hline
\end{tabular}

Sumber: Data diolah, 2018

Hasil uji reliabilitas menunjukkan bahwa ketiga instrumen penelitian memiliki koefisien Cronbach's Alpha lebih dari 0,60. Hal ini berarti semua instrumen telah reliabel, sehingga ketiga instrumen layak digunakan dalam penelitian.

Tabel 3.

Hasil Uji Reliabilitas

\begin{tabular}{lcl}
\hline \multicolumn{1}{c}{ Variabel } & Cronbach's Alpha & Keterangan \\
\hline Kepuasan Kerja $(\mathrm{Y})$ & 0,910 & Reliabel \\
Kompensasi Finansial $\left(\mathrm{X}_{1}\right)$ & 0,922 & Reliabel \\
Gaya Kepemimpinan Transformasional & 0,895 & Reliabel \\
$\left(\mathrm{X}_{2}\right)$ & 0,869 & Reliabel \\
Motivasi Kerja $\left(\mathrm{X}_{3}\right)$ & & \\
\hline
\end{tabular}

Sumber: Data diolah, 2018 
Variabel kepuasan kerja dapat diukur dengan penilaian, perasaan atau sikap seseorang atau karyawan terhadap pekerjaannya dan berhubungan dengan lingkungan kerja, jenis pekerjaan, kompensasi, hubungan antar teman kerja, dan hubungan sosial di tempat kerja. Hal tersebut memiliki masing-masing indikator berjumlah 6 yang kemudian dijadikan butir-butir pertanyaan. Jawaban responden pada variabel kepuasan kerja secara keseluruhan memiliki nilai rata-rata 4,07, hal ini berarti kepuasan kerja yang dirasakan oleh karyawan PT. Dua Ikan Lembongan tinggi. Pernyataan pertama memiliki rata-rata 4,18 yang berarti kepuasan karyawan terhadap kesempatan untuk menggunakan kemampuan mereka dalam melaksanakan tugas tinggi. Pernyataan kedua memiliki rata-rata 3,91 yang berarti banyak karyawan yang merasa puas dengan gaji yang diterimanya. Pernyataan ketiga memiliki rata-rata 4,09 yang berarti kepuasan karyawan mengenai lingkungan kerja yang sudah kondusif tinggi, artinya karyawan merasa nyaman dengan lingkungan mereka bekerja. Pernyataan keempat memiliki rata-rata 3,91 yang berarti para karyawan merasa puas terhadap rekan sekerja yang saling suportif dan mendukung. Pernyataan kelima memiliki rata-rata 4,22 yang berarti kepuasan mengenai pekerjaan yang sesuai dengan bidang yang dikuasai adalah sangat tinggi. Ini berarti, bahwa karyawan sudah merasa puas dengan pekerjaannya saat ini, karna sudah sesuai dengan bidang yang dikuasai. Pernyataan keenam memiliki rata-rata 4,13 yang berarti banyak karyawan yang merasa puas karena pekerjaan sudah sesuai dengan kemampuan yang dimiliki.

Variabel kompensasi finansial dapat diukur dengan 5 indikator yang kemudian dijadikan butir-butir pernyataan. Jawaban responden pada variabel 
kompensasi finansial secara keseluruhan memiliki nilai rata-rata 3,96, hal ini berarti kompensasi finansial yang diterima oleh karyawan PT. Dua Ikan Lembongan tinggi. Pernyataan pertama memiliki rata-rata 4,11 yang berarti gaji pokok yang diterima tinggi. Pernyataan kedua memiliki rata-rata 3,89 yang berarti insentif yang diberikan oleh perusahaan tinggi sehingga mencukupi kebutuhan hidup mereka. Pernyataan ketiga dan keempat memiliki rata-rata 4,04 dan 3,98 yang berarti tunjangan yang diberikan tinggi, sesuai tugas dan tanggung jawab. Pernyataan kelima memiliki rata-rata 3,78 yang berarti bonus yang diberikan oleh perusahaan sudah baik.

Variabel gaya kepemimpinan transformasional dapat diukur dengan 4 indikator. Jawaban responden pada variabel gaya kepemimpinan transformasional secara keseluruhan memiliki nilai rata-rata 4,19 yang artinya gaya kepemimpinan transformasional di PT. Dua Ikan Lembongan kuat. Pernyataan pertama memiliki rata-rata 4,20 yang berarti atasan telah memberikan kepercayaan penuh atas tugas yang diberikan. Pernyataan kedua memiliki rata-rata 4,13 berarti dorongan berupa motivasi yang diberikan pada karyawan saat bekerja sudah terlaksana dengan baik. Pernyataan ketiga memiliki rata-rata 4,22 berarti pimpinan sudah memiliki kreativitas yang baik dan mampu menciptakan ide-ide baru dalam proses perubahan. Pernyataan keempat memiliki rata-rata 4,20 yang berarti para karyawan sudah merasa diperhatikan dalam proses pengembangan karir dan prestasi.

Variabel motivasi kerja dapat diukur dengan 5 indikator yang kemudian dijadikan butir-butir pernyataan. jawaban responden pada variabel motivasi kerja secara keseluruhan memiliki nilai rata-rata 4,08 yang artinya motivasi atau 
dorongan semangat yang diterima karyawan di PT. Dua Ikan Lembongan tinggi. Pernyataan pertama memiliki rata-rata 4,22 yang berarti karyawan sudah merasa termotivasi karena sudah bekerja sesuai dengan keahlian dan kemampuan yang dimiliki. Pernyataan kedua memiliki rata-rata 4,24 berarti situasi dan kondisi kerja yang nyaman sangat baik, sehingga mampu memotivasi para karyawan. Pernyataan ketiga memiliki rata-rata 3,64 berarti atasan sudah memberikan fasilitas rekreasi, seperti liburan terhadap para karyawannya. Pernyataan keempat memiliki rata-rata 4,13 yang berarti para karyawan sudah merasa termotivasi karena atasan selalu memberikan promosi terhadap karyawan yang berprestasi. Pernyataan kelima memiliki rata-rata 4,16 yang berarti jaminan kesehatan yang diberikan oleh perusahaan tinggi dan sesuai dengan kebutuhan karyawan.

Adapun hasil analisis regresi dengan program statitical pacage of social science (SPSS) versi 17.0 for Windows.

$\begin{array}{lllllll}\mathrm{Y} & = & -3,117+0,334 \mathrm{X}_{1}+0,848 \mathrm{X}_{2}+0,333 \mathrm{X}_{3} & \mathrm{R}^{2} \\ & & & & & 0,899 \\ \mathrm{SE} & = & (1,585) & (0,080) & (0,137) & (0,122) & \\ \mathrm{t} & = & -2,004 & 4,167 & 6,191 & 2,724 \\ \text { Sig uji t } & = & 0,052 & 0,000 & 0,000 & 0,009 \\ \mathrm{~F} & = & 121,837 & & & \\ \text { Sig F } & = & 0,000 & & \end{array}$

Berdasarkan hasil analisis regresi linier berganda dapat ditulis persamaan regresi linear berganda sebagai berikut.

$$
\mathrm{Y}=0,334 \mathrm{X}_{1}+0,848 \mathrm{X}_{2}+0,333 \mathrm{X}_{3}
$$

Dimana :

$$
\begin{array}{ll}
\mathrm{Y} & =\text { Kepuasan kerja } \\
\mathrm{X}_{1} & =\text { Kompensasi finansial } \\
\mathrm{X}_{2} & =\text { Gaya kepemimpinan transformasional } \\
\mathrm{X}_{3} & =\text { Motivasi kerja } \\
\mathrm{R}^{2} & =\text { Koefisien determinasi }
\end{array}
$$


Berdasarkan persamaan hasil regresi linear berganda melalui uji SPSS, dapat dijelaskan hal-hal bahwa nilai koefisien $b_{1}=0,334$ berarti menunjukkan bahwa kompensasi finansial $\left(\mathrm{X}_{1}\right)$ berpengaruh positif dan signifikan terhadap kepuasan kerja (Y). Nilai koefisien $\mathrm{b}_{2}=0,848$ berarti menunjukkan bahwa gaya kepemimpinan transformasional $\left(\mathrm{X}_{2}\right)$ berpengaruh positif dan signifikan terhadap kepuasan kerja $(Y)$. Nilai koefisien $b_{3}=0,333$ berarti menunjukkan bahwa motivasi kerja $\left(\mathrm{X}_{3}\right)$ berpengaruh positif dan signifikan terhadap kepuasan kerja $(\mathrm{Y})$. Nilai $\mathrm{R}^{2}$ $=0,899$ berarti sebesar 89,9 persen kepuasan kerja dipengaruhi oleh kompensasi finansial, gaya kepemimpinan transformasional, dan motivasi kerja.

Pengujian ini dilakukan untuk mengetahui tingkat signifikansi pengaruh variabel bebas secara bersama terhadap variabel terikat. Uji F dilakukan dengan membandingkan nilai $F_{\text {hitung }}$ dengan nilai $F_{\text {tabel }}$ pada taraf signifikansi 0,05 . Berdasarkan hasil perhitungan regresi linear berganda yang dirangkum pada tabel 4.9 dapat diketahui bahwa $F_{\text {hitung }}=121,837$ dan nilai $F_{\text {tabel }}$ dengan tingkat keyakinan 95 persen dan $\alpha=0,05 ; \mathrm{df}=(\mathrm{k}-1) ;(\mathrm{n}-\mathrm{k})=(2 ; 42)$ adalah sebesar 3,23 (lampiran 6). Oleh karena $F_{\text {hitung }}(121,837)$ lebih besar dari $F_{\text {tabel }}(3,23)$ dengan nilai signifikansi 0,000<0,05 maka dapat disimpulkan kompensasi finansial, gaya kepemimpinan transformasional, dan motivasi kerja berpengaruh positif dan signifikan secara serempak terhadap kepuasan kerja. Ini berarti model dapat digunakan untuk analisa lebih lanjut atau dengan kata lain model dapat digunakan untuk dipresentasikan karena hasil yang sudah baik.

Nilai koefisien determinasi $\mathrm{R}^{2}$ memiliki nilai yang tinggi yaitu 0,899 hal ini menandakan bahwa sebesar 89,9 persen variasi kepuasan kerja dipengaruhi oleh 
kompensasi finansial, gaya kepemimpinan transformasional, dan motivasi kerja, sedangkan sisanya 10,1 persen dipengaruhi oleh faktor-faktor lain diluar penelitian.

Kompensasi finansial adalah segala sesuatu yang diterima pegawai dalam bentuk uang (finansial) sebagai balas jasa atau kontribusi terhadap perusahaan atau organisasi. Berdasarkan hasil hipotesis, pengaruh antara kompensasi finansial dalam penelitian ini diperoleh nilai koefisien beta sebesar 0,334 dengan nilai signifikansi 0,000 yang lebih kecil dari 0,05 sehingga $\mathrm{H}_{0}$ ditolak dan $\mathrm{H}_{1}$ diterima, yang mengindikasi bahwa kompensasi finansial berpengaruh positif dan signifikan terhadap kepuasan kerja. Hasil tersebut menunjukan bahwa semakin tinggi kompensasi finansial yang diberikan maka semakin tinggi kepuasan kerja karyawan pada PT. Dua Ikan Lembongan.

Pemaparan tersebut konsisten dengan penelitian yang dilakukan oleh Anas (2013), Mabaso \& Dlamini (2017), Sedhana \& Mudiartha (2014), Adeoye et al. (2014), dan Muguongo et al. (2015) yang menemukan adanya pengaruh positif dan signifikan pada variabel kompensasi finansial terhadap kepuasan kerja.

Gaya kepemimpinan transformasional merupakan suatu cara pemimpin dalam memengaruhi perilaku karyawannya agar mampu bekerjasama dan bekerja secara produktif untuk mencapai tujuan organisasi. Berdasarkan hasil hipotesis, pengaruh antara gaya kepemimpinan transformasional dalam penelitian ini diperoleh nilai koefisien beta sebesar 0,848 dengan nilai signifikansi 0,000 yang lebih kecil dari 0,05 sehingga $\mathrm{H}_{0}$ ditolak dan $\mathrm{H}_{1}$ diterima, yang mengindikasi bahwa gaya kepemimpinan transformasional berpengaruh positif dan signifikan terhadap kepuasan kerja. Hasil tersebut menunjukan bahwa semakin kuat pengaruh gaya 
kepemimpinan transformasional maka semakin tinggi kepuasan kerja karyawan pada PT. Dua Ikan Lembongan.

Pemaparan tersebut konsisten dengan penelitian yang dilakukan oleh Reidy et al. (2016), Voon et al. (2011), Belias \& Athanasios (2014), Hanifah \& Arifin (2016), Aqmarina (2016), Mujkic et al. (2014), dan Alghamdi et al. (2018) yang menyatakan bahwa gaya kepemimpinan transformasional berpengaruh positif dan signifikan terhadap kepuasan kerja karyawan.

Motivasi kerja adalah sesuatu yang menimbulkan dorongan atau semangat kerja atau pendorong semangat kerja, serta meningkatkan kepuasan kerja karyawan guna membantu perusahaan untuk meningkatkan kinerjanya. Berdasarkan hasil hipotesis, pengaruh antara motivasi kerja dalam penelitian ini diperoleh nilai koefisien beta sebesar 0,333 dengan nilai signifikansi 0,009 yang lebih kecil dari 0,05 sehingga $\mathrm{H}_{0}$ ditolak dan $\mathrm{H}_{1}$ diterima, yang mengindikasi bahwa motivasi kerja berpengaruh positif dan signifikan terhadap kepuasan kerja. Hasil tersebut menunjukan bahwa semakin tinggi motivasi kerja yang diberikan maka semakin tinggi kepuasan kerja karyawan pada PT. Dua Ikan Lembongan.

Pemaparan tersebut konsisten dengan penelitian yang dilakukan oleh Rajan (2015), Nadia (2011), Olutade et al. (2015), Murti \& Srimulyani (2013), Breaugh et al. (2017) dan Sarita \& Agustia (2011) yang menyatakan bahwa motivasi kerja berpengaruh positif dan signifikan terhadap kepuasan kerja karyawan.

Implikasi dari hasil penelitian ini dibagi menjadi dua bagian, yaitu implikasi teoritis dan implikasi praktis. Implikasi teroritis adalah hal-hal yang perlu dilakukan peneliti berikutnya dalam mengembangkan hasil penelitian ini, sedangkan 
implikasi praktis adalah hal-hal yang perlu diperhatikan terkait dengan pihak perusahaan khususnya pada PT. Dua Ikan Lembongan berkaitan dengan hasil penelitian. Implikasi praktis dan implikasi teoritis bahwa bagi peneliti selanjutnya yang mengangkat topik sejenis diharapkan dapat menambah indikator yang belum dimasukan dalam penelitian ini, menggunakan perusahaan yang berbeda, serta mengukur variabel lain yang memengaruhi kepuasan kerja. Berdasarkan data responden karyawan dapat dilihat bahwa semua variabel yaitu kompensasi finansial, gaya kepemimpinan transformasional, dan motivasi kerja memiliki pengaruh positif dan signifikan terhadap kepuasan kerja karyawan. Dengan demikian pihak manajemen PT. Dua Ikan Lembongan diharapkan memperhatikan aspek-aspek yang memengaruhi kepuasan kerja karyawan seperti kompensasi finansial, gaya kepemimpinan transformasional, dan motivasi kerja, karena pentingnya aspek-aspek tersebut yang akan berdampak pada kinerja organisasi.

\section{SIMPULAN DAN SARAN}

Berdasarkan hasil analisis dan penelitian yang telah diuraikan mengenai pengaruh kompensasi finansial, gaya kepemimpinan transformasional dan motivasi kerja terhadap kepuasan kerja karyawan (studi pada PT. Dua Ikan Lembongan), maka diperoleh simpulan bahwa kompensasi finansial berpengaruh positif dan signifikan terhadap kepuasan kerja. Ini berarti semakin tinggi kompensasi finansial yang diberikan perusahaan, maka semakin tinggi kepuasan kerja karyawan.

Gaya kepemimpinan transformasional berpengaruh positif dan signifikan terhadap kepuasan kerja. Ini berarti semakin kuat kepemimpinan transformasional, maka semakin tinggi kepuasan kerja karyawan dalam bekerja di perusahaan. 
Motivasi kerja berpengaruh positif dan signifikan terhadap kepuasan kerja. Ini berarti semakin tinggi motivasi yang diberikan kepada karyawan, maka semakin tinggi kepuasan kerja karyawan.

Berdasarkan pembahasan hasil penelitian dan simpulan pada bab sebelumnya, maka dapat dikemukakan beberapa saran yaitu tanggapan responden pada variabel kompensasi finansial memperlihatkan indikator terendah yaitu bonus karyawan yakni karyawan merasa bonus yang diberikan kurang sesuai dengan besarnya keuntungan yang didapat perusahaan, namun indikator tersebut masuk dalam kategori tinggi. Saran bagi pihak manajemen PT. Dua Ikan Lembongan mengenai bonus karyawan agar memperhatikan keseimbangan antara keuntungan perusahaan dan pembagian bonus bagi karyawan.

Tanggapan responden pada variabel gaya kepemimpinan transformasional memperlihatkan indikator terendah yaitu motivasi yakni rendahnya kemampuan pemimpin untuk memberikan motivasi kepada karyawan, namun indikator tersebut masuk dalam kategori kuat. Saran bagi pihak manajemen PT. Dua Ikan Lembongan mengenai motivasi agar lebih memperhatikan semangat kerja karyawan dengan selalu memberikan motivasi dalam bekerja.

Tanggapan responden pada variabel motivasi kerja memperlihatkan indikator terendah yaitu fasilitas rekreasi yakni karyawan merasa fasilitas rekreasi yang diberikan perusahaan seperti liburan ke tempat rekreasi belum cukup terealisasikan, namun indikator tersebut masuk dalam kategori tinggi. Saran bagi pihak manajemen PT. Dua Ikan Lembongan mengenai fasilitas rekreasi agar memberikan 
waktu bagi para karyawan untuk berlibur bersama namun tetap memperhatikan jadwal kerja.

Tanggapan responden pada variabel kepuasan kerja memperlihatkan 2 indikator terendah yaitu mengenai gaji pokok yang diterima tidak sesuai dengan pekerjaan yang dilakukannya, dan rekan sekerja, dimana lingkungan dalam bekerja khususnya teman sekerja memiliki sifat yang tidak selalu suportif. Namun indikator tersebut masuk dalam kategori tinggi. Saran bagi pihak manajemen PT. Dua Ikan Lembongan mengenai gaji pokok dan rekan sekerja yakni, memperhatikan keseimbangan gaji pokok dengan pekerjaan yang dilakukan dan lingkungan kerja karyawan agar lebih kondusif.

Bagi peneliti selanjutnya diharapkan dapat memperluas cakupan lokasi dan mengkaji lebih banyak sumber maupun referensi serta mempertimbangkan variabel-variabel lain seperti budaya organisasi, loyalitas karyawan dan lain sebagainya yang dapat memengaruhi kepuasan kerja karyawan.

\section{REFERENSI}

Adeoye, Abayomi Olarewaju \& Ziska Fields. (2014). Compensation management and employee job satisfaction: a case of Nigeria. J Soc Sci. 41 (3): 345-352.

Alghamdi, Mohammed G., Topp, Robert., \& AlYami, Mansour S. (2018). The effect of gender on transformational leadership and job satisfaction among Saudi nurses. Journal Adv. Nurs. 74: 119-127.

Anas, Khaidir. (2013). Pengaruh kompensasi dan lingkungan kerja terhadap kepuasan kerja karyawan PT. Karya Mitra Muda. Jurnal Ekonomi, Universitas Negeri Padang. 2 (1): 1-11.

Aqmarina, Nur Septi., Hamidah Nayati Utami., \& Arik Prasetya. (2016). Pengaruh kepemimpinan transformasional dan transaksional terhadap kepuasan kerja dan kinerja karyawan (Studi pada karyawan hotel Gajahmada Graha Malang). Jurnal Administrasi Bisnis (JAB). 35 (2): 164-173. 
Ardana, I Komang., Ni Wayan Mujiati., \& I Wayan Mudiartha Utama. (2012). Manajemen Sumber Daya Manusia. Yogyakarta: Graha Ilmu.

Belias, Dimitrios., \& Koustelios, Athanasios. (2014). Transformational leadership and job satisfaction in the Banking Sector: A Review. International Review of Management and Marketing. 4 (2): 187-200.

Breaugh, Jessica., Adrian Ritz., \& Kerstin Alfes. (2017). Work motivation and public service motivation: disentangling varieties of motivation and job satisfaction. Journal Public Management Review. 20 (10): 1423-1443.

Dessler, Gary. (2007). Manajemen Sumber Daya Manusia. Edisi Kesepuluh. Jilid 2. Jakarta: PT. Indeks.

Girma, Samson. (2016). The relationship between leadership style and employee job satisfaction study of federal and Addis Ababa sport organizational management setting in Ethiopia. International Journal of Applied Research. 2 (3): 92-96.

Hanifah., \& Zainal Arifin. (2016). Pengaruh gaya kepemimpinan transpormasional, transaksional dan laissez faire terhadap kepuasan kerja pegawai pada pemerintahan kota Banjarmasin. Jurnal Spread. 6 (2): 27-38.

Homberg, Fabian., Dermot McCarthy., \& Vurain Tabvuma. (2015). A metaanalysis of the relationship between public service motivation and job satisfaction. Public Administration Review. 75 (5): 711-722.

Mabaso, Calvin M., \& Dlamini, Bongani I. (2017). Impact of compensation and benefits on job satisfaction. Journal Business Manage. 11 (2): 80-90.

Muguongo, Mary M., Muguna, Andrew T., \& Muriithi, Dennis K. (2015). Effects of compensation on job satisfaction Among Secondary School Teachers in Maara Sub - Country of Tharaka Nithi County, Kenya. Journal of Human Resource Management. 3 (6): 47-59.

Mujkic, Alisa., Sehic, Dzevad., Rahimic, Zijada., \& Jusic, Jasmin. (2014). Transfomational leadership and employee satisfaction. UDK 65.012.431. 497 (6): 259-270.

Murti, Harry., \& Veronika A. Srimulyani. (2013). Pengaruh motivasi terhadap kinerja pegawai dengan variabel pemediasi kepuasaan kerja pada PDAM kota Madiun. Jurnal Riset Manajemen dan Akuntansi. 1 (1): 10-17.

Nadia, Ayub. (2011). Relationship between work motivation and job satisfaction. Pakistan Business Review. 13 (2): 332-347. 
Narsa, I Made. (2012). Karakteristik kepemimpinan: Transformasional versus transaksional. Jurnal Manajemen dan Kewirausahaan. 14 (2): 102-108.

Nyenyembe, Fabian W., Ralf Maslowski., Beatrice S. Nimrod. \& Levina Peter. (2016). Leadership styles and teachers' job satisfaction in Tanzanian public secondary schools. Universal Journal of Educational Research. 4 (5): 980988.

Olutade M., Liefooghe A. \& Olakunle A.O. (2015). Influence of entrepreneurial leadership skills on employees' motivation and job satisfaction: a leader member exchange (LMX) approach. International Journal of Academic Research in Business and Social Sciences. 5 (9): 118-214.

Priansa, Donni Juni. (2014). Perencanaan \& Pengembangan SDM. Bandung: Alfabeta.

Rajan, D. (2015). Motivation and job satisfaction: A study of pharmacists in Private Hospital. Samvad. 9 (2): 87-100.

Reidy, Muhammad., Mochamad Djudi., \& Yuniadi Mayowan. (2016). Pengaruh gaya kepemimpinan transformasional dan transaksional terhadap kepuasan kerja karyawan (Studi pada CV Kalingga Jaya di Jakarta). Jurnal Administrasi Bisnis (JAB). 35 (1): 110-119.

Rivai, Veithzal. (2005). Manajemen Sumber Daya Manusia. Jakarta: Murai Kencana.

Robbins, Stephen P. (2001). Perilaku Organisasi. Edisi 8. Jakarta: Pearson Education Asia Pte. Ltd dan PT. Prenhallindo.

Robbins, Stephen P., \& Timothy A. Judge. (2017). Perilaku Organisasi. Edisi 16. Jakarta: Selemba Empat.

Sarita, Jena., \& Dian Agustia. (2011). Pengaruh gaya kepemimpinan situasional, motivasi kerja, locus of control terhadap kepuasan kerja dan prestasi kerja auditor. SIAE. 3 (2): 1-29.

Sedhana Yasa, I Putu., \& I Wayan Mudiartha Utama. (2014). Pengaruh kompensasi dan lingkungan kerja terhadap kepuasan kerja dan kinerja karyawan pada Karma Jimbaran. E-Jurnal Manajemen Unud. 3 (3): 609-623.

Siregar, Edi. (2011). Pengaruh motivasi kerja, kinerja individual, dan sistem kompensasi finansial terhadap kepuasan kerja. Jurnal Pendidikan Penabur. 16: 81-93. 
Thamrin, H. M. (2012). The influence of transformational leadership and organizational commitment on job satisfaction and employee performance. International Journal of Innovation, Management and Technology. 3 (5): 566-572.

Voon, M.L., Lo, M.C., Ngui, K.S., \& Ayob, N.B. (2011). The influence of leadership styles on employees' job satisfaction in public sector organizations in Malaysia. International Journal of Business, Management and Social Sciences. 2 (1): 24-32.

Yudi P. Jaya, Kadek., \& I Gst. Ayu D. Adnyani. (2015). Pengaruh gaya kepemimpinan terhadap disiplin kerja pegawai di dinas balai bahasa provinsi Bali. E-Jurnal Manajemen Unud. 4 (9): 2702-2721.

Yukl, Gary. (2010). Kepemimpinan dalam organisasi. Jakarta: PT Indeks. 